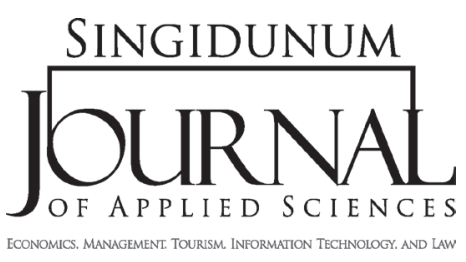

\section{CULTURAL IDENTITY AND CULTURAL TOURISM \\ - BETWEEN THE LOCAL AND THE GLOBAL (A CASE STUDY OF PULA, CROATIA)}

\section{Nataša Urošević*}

University of Pula, Interdisciplinary Study Programme of Culture and Tourism, 1/1 Preradovićeva Street, Pula, Croatia

\begin{abstract}
:
Cultural identity and tourism are today inevitably linked: in the globalized world of unified values and dramatic economic, political and social changes, tourism becomes an opportunity for cultural and social contact, communication and cultural exchange. A growing need for confirmation of local cultural identities as well as the tourists search for identity could be seen as a response to the globalization of cultural trends. In this paper we set the hypothesis that the cultural tourism, as a sustainable alternative to mass tourism, represents the best model for local development in the turbulent global context, because it optimally uses the authentic characteristics of destinations and the unique elements of identity to differentiate them from competitors. In this way, it protects and strengthens the cultural identity, values, lifestyle and economy of local communities. To test our hypothesis, we conducted a primary research. We used a hybrid methodological strategy, combining quantitative and qualitative methods in order to examine 417 tourists, 296 local residents and 15 experts. We have conducted parallel content analysis of monographs and multimedia resources. Collected data have shown that the key elements of the destination identity are heritage tourism, creative industries, multiculturality and the local way of life.
\end{abstract}

SINGIDUNUM JOURNAL 2012, 9 (1): 67-76

ISSN 2217-8090

UDK 338.48-6:7/8:338.482(497.5)

Original paper/Originalni naučni rad

\section{Key words:}

cultural identity, cultural tourism, destination management, Pula.

\section{INTRODUCTION}

In the context of dramatic economic, political and social changes that are shaking the world, cultural tourism has an important role in communicating the core values of intercultural dialogue, protection and promotion of cultural diversity and preservation of cultural heritage, whose tangible and intangible assets constitute the important part of the cultural identity. Cultural tourism, which is best related to the changes in preferences of (post)modern tourists and requirements of sustainable develop- ment (in other words: which cares for the culture it consumes while culturing the consumer), helps to reconfirm the importance of our own cultures while improving intercultural communication, respecting other cultures and deepening mutual understanding and solidarity among different ethnic, national, religious and linguistic entities.

In the cultural tourism communication process, seen as creative and stimulating interaction of elements between different cultures and individuals, local values and identities interact and interface with development of global cultural demands. Many 
local communities are now actively trying to identify and develop their tangible and intangible cultural assets as the means of developing comparative advantage in an increasingly competitive tourism marketplace, and to create local distinctiveness in the face of globalisation. In addition to neutralizing the negative effects of traditional forms of tourism, regeneration and protection of cultural heritage treasures, contribution to employment and sustainable economic growth, the fundamental advantage of cultural tourism is that, by using the heritage treasury, with a minimal investment, it attracts the fast-growing segment of cultural tourists, which consumption is not significantly affected by fluctuations in the global market.

Combination of cultural and tourism development policies acts as a catalyst, promoting the local destination as the most desirable place to live, work, visit and invest in. Investing in cultural tourism can significantly improve the quality of life of local residents and their guests, regenerate derelict urban areas and increase the value of real estates. We will test this model in the case study of Pula and Istria, and explore concrete possibilities of development of cultural and creative tourism through events and attractions covering the most recognizable elements of heritage and identity (the Roman heritage, Austrian fortresses, Mediterranean and Central European identity). Our hypothesis was that development of cultural and creative tourism models could solve some typical problems of Croatian Adriatic destinations such as seasonality, revitalize the Old Town, increase employment and attract the recession-resistant segments of tourists. To test our hypothesis, we have conducted a primary research in Pula, in order to collect information for the situation analysis and strategic planning of cultural tourism. We have examined 417 tourists, 296 local residents and 14 experts. The main objective of our research has been to assess the key stakeholders' perceptions and perspectives of Pula as a cultural tourism destination and to define the key elements of its cultural identity, which makes the city unique and recognizable in the perception of its guests and residents. We have combined the quantitative and qualitative methods: the survey method has been conducted and questionnaire technique has been used to collect some data from tourists, local population and cultural tourism experts. We have conducted parallel content analysis of monographs and multimedia resources about Pula. One of the aims was also to train future professionals for the research and criti- cal reflection of the development of their communities. Therefore, the study has included students of the second and third year of Interdisciplinary Study Programme of Culture and Tourism at the Juraj Dobrila University of Pula, who have surveyed tourists and local residents, interviewing experts in related fields and critically exploring secondary sources.

\section{THEORETICAL FRAMEWORK: CULTURAL IDENTITY, CULTURAL TOURISM AND GLOBALISATION}

Nowadays, cultural identity and tourism are inevitably linked: in the globalized world of unified values and dramatic economic, political and social changes, we define tourism primarily as an opportunity for cultural and social contact, communication and cultural exchange with other individuals and cultures. In this communication process, seen as creative and stimulating interaction among different cultures and lifestyles, local values and identities interact and interface with heterogeneous cultural demand, that changes simultaneously on the global, local and individual level. Therefore cultural tourism does not provide exclusively an opportunity for the protection and preservation of local cultures and heritage, as an authentic expression of cultural identity in the globalization process. At the same time it also affects the cultural identity of the travelling individual and the visiting community. Tourists travel because they look for a new experience, different from their everyday life; they wish to learn something new about themselves and the world around them, and they seek for the new identities. Thus their cultural identity constantly changes in the process of exploring different worlds in pursuit of this new, added quality of life. The visiting community also changes, in both positive and negative sense. For many developing countries tourism is the only way to participate in the global economy and to develop their own economies (Jelinčić, 2009). At the same time tourism, offering a standardized and unified experiences and products, degrades local values and the environment. In this sense, we set the hypothesis that the cultural tourism, which "cares for the culture it consumes while culturing the consumer" (Richards, 2007b), as a sustainable alternative to mass tourism, represents the best model for local tourism development in the turbulent global context, because it optimally uses the authentic characteristics of destinations and the unique elements 
of their cultural identity to differentiate them from competitors and to position themselves better in the global market. In this way, it protects cultural heritage and strengthens the cultural identity, values, lifestyle and economy of local communities. At the same time, it enables intercultural dialogue and sustainable development, promoting cultural diversity and a common European identity (Jelinčić, 2010).

One of the objectives of cultural tourism is the sustainable use of cultural distinctiveness as a tourist resource. The concept that could be applied here is from the UNESCO's report Our Creative Diversity, where culture is defined as the whole complex of distinctive spiritual, material, intellectual and emotional assets that characterize a society or a social group, and which includes creative expression (eg. oral history, language, literature, performing arts, fine arts and crafts), community practices (celebrations and patterns of social interaction that contribute to group and individual welfare and identity), and material or built forms such as sites, buildings, historic city centres, landscapes, art, and objects (UNESCO, 1995). Therefore the concept of culture we use and perceive as a process, includes what people think, do, create, and exchange with others. Culture could be defined also as a „living identity“. Culture and cultural heritage, as an expression of identity and history of the people they belong to, could serve also as a tool for the establishment of identities and differences, which at the same time localize and globalize the cultural and tourist experience, characterized by contact and mixing of cultures (Jelinčić, 2009).

The modern tourists' requests for authentic cultural experiences and unique local products could be seen as the response to globalization processes in tourism. According to Richards, if globalization is observed in terms of an increasing integration of economic, social and cultural systems, then tourism can be considered both as a cause and an effect of a globalization process. Namely, rising education levels, on the global level, enable more people to access culture, while the effects of globalization create more interest in distant cultures as well as in local heritage. On the other hand, the processes of cultural globalization accelerate the exchange of cultural symbols among people around the world, leading to changes in local popular cultures and identities (Richards, 2007b). In this respect, a growing need for the confirmation of local cultural identity could be actually seen as a response to the globalization of cultural trends. So the appreciation of distinctive culture characteristics has become the central concept in the reflection of the contemporary cultural tourism (Ivanovic, 2008), which could be defined as the tourism of special interests, covering visits of people outside their permanent place of residence, completely or partly motivated by the interest in history, arts, heritage and lifestyle of the location, region, group or institution. The term refers to both tangible and intangible dimensions of culture, and we consider visitors to be cultural tourists if they are at least partly motivated by a desire to participate in cultural activities (Jelinčić, 2009). The UN World Tourism Organisation defines cultural tourism as travelling with the aim of learning about foreign cultures, presentation of one's own art work, the visiting of festivals, cultural sight seeing, etc. In a certain respect, all tourist trips could be considered as cultural tourism, because they „satisfiy tourists' needs to learn about foreign countries and raises their cultural level, knowledge and experiences by meeting other people" (Richards, 2007b).

According to the UNWTO, cultural tourism includes 40 percent of the total number of trips in the international tourism, and this share is constantly growing at a rate of as much as 15 percent annually. At the same time, experts estimate that more than $50 \%$ of tourist visits in Europe are motivated by cultural heritage, and cultural tourism has the highest growth rate in the entire tourism sector (Richards, 2010). Obviously, it is the market on the rise bringing visitors of higher education, expectations and consumption. The new, postmodern type of tourist is also interested in creative tourism, as a new generation of tourism, which involves an authentic experience and engagement in the real cultural life of the social community in the destination. It is based on the expression of individual's creative potential and the self-creation of the tourist experience, and incudes more educational, emotional, social and participative interaction with the place, its living culture and the local people.

European and wider global trends and experiences indicate that continuous and increased demand for this form of tourism is followed by substantial improvements in market supply, growing international competition of cities and regions of culture and the transition from specialized market niches in the mass market. Parallel to the emphasis on cultural distinctiveness and heritage rather than prevailing natural attractive factors, diversification and differentiation of standardized destination products and reorientation from "high" and the elite to the 
consumption of popular culture and an interest in exploring the everyday life of the local population are included.

The purpose of this research was to explore the essential elements of cultural identity and heritage which could differentiate and better position the destination in the global tourism market, improve the cultural and creative tourism development, reduce seasonality, contribute to employment, sustainable economic growth and quality of life, regenerate derelict urban areas and increase the value of real estates in typical Adriatic (Mediterranean) destinations such as Pula. We will test this model in the case study of Pula and Istria, and explore concrete possibilities of development of cultural tourism.

\section{METHODOLOGY:}

\section{A HYBRID APPROACH}

To explore concrete possibilities of cultural tourism development, and to identify key elements of cultural identity and destination image in the global tourism market, we have combined quantitative and qualitative methods: the survey method has been conducted and questionnaire technique has been used to collect data from tourists, local population and cultural tourism experts. The main goal has been to assess different interest groups' perceptions and perpectives of Pula as a cultural tourism destination and to define the key elements of its cultural identity, which makes the city unique and recognizable on the cultural map of Europe and in the perception of its guests and residents. We have conducted parallel content analysis of monographs and multimedia resources about Pula. One of the aims has also been to train future professionals for the research and critical reflection of the development of their communities. Therefore, the study has included students of the second and third year of Interdisciplinary Study Programme of Culture and Tourism at the Juraj Dobrila University of Pula, who have surveyed tourists and local residents, and interviewing experts in related fields.

We have used a hybrid methodological strategy, combining survey and interviews to examine 417 tourists, 296 local residents and 15 experts. The first phase of the research has been conducted intentionally during April and May in the Pula old town, to explore attitudes and preferences of guests who visit the town off-season. Our assumption has been that they could be potentially interested in the segment of cultural tourists whose characteristics and preferences are the most important considering the development of cultural and creative tourism in the area. In the tourists survey we have used a questionnaire comparable to ATLAS Cultural Tourism Research questionnaire (Richards, 2007a) and to TOMAS Cultural Tourism Research (Institute for Tourism, 2008; 2009). We have used partially modified ATLAS questionnaire with additional questions about experiences and attitudes of respondents related to cultural identity and cultural tourism development perspectives in the city, with their proposals and suggestions for the cultural tourism improvement. The visitors have been asked about their socio-demographic profile, the main motivation and the holiday type, the level of satisfaction with the stay in the destination and attractions they have visited, sources of information regarding the destination, the type of accomodation and the lenght of stay. Also, they have been asked about distinctive elements of the city identity and characteristics they have, most and least, liked, as well as recommendations for improving the cultural tourism offers. Both open and closed questions have been included. Questionnaires, translated into English, German and Italian, and containing 21 questions, have been the basic instrument for gathering information. The sample has been occasional including visitors of the Pula old city centre.

In the first phase we have also surveyed the sample of 296 randomly intercepted local residents. They havr been asked about their socio-demographic data, their perceptions of Pula both as a cultural tourist destination and a place of residence, and sugestions towards cultural tourism development. The special group of questions has focused on cultural identity and distinctive and unique characteristics of the city. We have examined the attitudes of the local residents related to strengths,weaknesses, opportunities and threats of the cultural tourism offerings as the inputs for the strategic analysis. We have also explored their awareness, satisfaction, sources of information and frequency of visits to cultural events in the city. We have been interested in the degree of awareness of the importance of cultural heritage and the perception of cultural events, and the opinion on the city's candidacy for European Capital of Culture. Both open and closed questions have been included. A five-point Likert scale has been used for the measurement of notions.

For interviewing experts, we have used semistructured interview in which we have asked them to describe the current situation in the field of culture 
and tourism in the city, to list the main problems and development priorities and to offer a strategic vision. We have asked them about the current and desired identity and image of the city, and the manner in which the city has been perceived by its inhabitants, visitors and potential investors. In conclusion, we have asked them whether projects such as the European Capital of Culture could strategically direct the city towards the development of the synergy between culture and tourism, and about the prospects in education and employment in the field of culture and tourism.

Qualitative research has included content analysis of monographs and multimedia sources about Pula, such as the Internet.

\section{RESULTS}

\section{Tourists}

The obtained data show that most tourists, who visit the city off-season, come on their holiday and that culture is one of the most important motives to visit the city. The collected data show that Pula could be considered a typical cultural tourism destination, with an emphasis on heritage tourism and creative industries. Although one third of guests have said that the sun and the sea have been the main motive of their visit, a half of the respondents have cited urban, cultural and creative tourism as the main motive for the visit. Almost a third travels intentionally to visit the cultural attractions or events in Pula, which is more than the Croatian (26\%, according to TOMAS Cultural Tourism 2008) and the European average (25\% according to ATLAS Cultural Tourism Research). Many of them combine the classic sun/beach holiday with wellness and eco-tourism, cultural/creative tourism, rest in the countryside, or visiting the city. Foreigners are often interested in opportunities for shopping in the old town. Shopping as a motive often goes with urban tourism/visiting the city. Almost half, more precisely $44 \%$ of 419 interviewed tourists had already visited Pula and Istria. They spent in Pula on average 5.5 nights. Most of them, $47 \%$ stayed at the hotel, $37 \%$ in private accommodation, $9 \%$ in a camp and $7 \%$ in other forms of accommodation (friends and relatives, hostels, couch-surfing). Most of them were very pleased with the stay in the destination: the most frequent rating was 8 out of 10 , and the average rating 8.7 .
They have liked, most of all in Pula (open question): cultural heritage/history (115 answers or $27 \%$ ), the sea, beautiful beaches, nature and climate (58), the Arena (45) and people (37). We can conclude that the main positive associations related to the identity and image of the city were: culture, history, beautiful nature, pleasant climate, kind people and Arena as the iconic symbol of the city. Tourists perceive Pula primarily as a city of rich cultural and historical heritage, surrounded by beautiful nature and the sea, with mild climate, relaxed atmosphere and friendly hosts, recognizable for its Roman amphitheatre.

Most complaints (open questions) have been related to problems with traffic and parking, the neglected old town, lack of entertainment and places to go out, old town infrastructure, etc.

Recommendations for the improvement of cultural tourism have been related mostly to improvement of entertainment attractions, events and places to go out (especially in the evening and out of season), extension of working time of shops and restaurants, investments in the renovation of the old city centre ("clean, renovate and revive the old city core!”), improvement of information and signaling, and improvement of the gastronomic offer.

Speaking of attractions, most (a half) of respondents are interested in cultural and historical monuments (primarily Arena, 25\% of them), then museums (more than a third), protected natural heritage (a third), and religious sites. It is interesting to notice that a lot of tourists are interested to visit the cinema and theatre, which means that it would be advisable to prepare some special programs for them (in foreign languages).

Regarding the organization of trips, about onethird uses all-inclusive packages, a third has booked accommodation and transport separately and 35\% have booked nothing in advance (self-organized trip). Far the most common source of information is the Internet, it has been used by two thirds of the guests, and this very high proportion of new technology users differs our sample from ATLAS and TOMAS Cultural Tourism Research. It is followed by family and friends (47\%) as a source of information, an earlier visit (21\%), a tourist agency (19\%), guide books (9\%) and brochures.

The last group of questions has focused on sociodemographic profile. It has been found that most respondents (81\%) have been foreign tourists, most of them from Italy (23\%), Germany (17\%), Austria (10\%), the United Kingdom (8\%) and Slovenia 
(7\%). The share of respondents from Croatia has been $19 \%$.

More than a half of respondents have been female $(51 \%)$ and $49 \%$ of them have been male. Most respondents have been young (20-29: 25\% or total of $37 \%$ younger than 30 and middle-aged (30-39: 28\%, 40-49: 23\%). In total, there are $47 \%$ guests in the age group from $30-49$ (the same proportion as in TOMAS Cultural Tourism 2008). A minor part is in the age group $50-59(11 \%)$ and $8 \%$ are older than 60 . Most of the respondents, $40 \%$ have a university degree, approximately equal proportion is for secondary school qualifications (39\%), and $18 \%$ of them have masters or doctorates. The quarter of the total number of respondents (26\%) has a culturerelated job, which is in line with the European average (30\%) and considerably more than the Croatian average (13\% according to TOMAS Cultural Tourism 2008).

\section{Local residents}

In the first phase of the research we have surveyed the sample of 196 randomly intercepted local residents. Among the respondents, 55\% have been female, and $45 \%$ male; $55 \%$ have secondary school qualifications (most of them are students), 39\% have a university degree, $3 \%$ master or doctorate, and 3\% elementary school.

Firstly, they have been asked about their perception of the city. On a scale of 1-5, the statement "Pula is a tourist city" has got an average rating of 3.65. The statement „Pula is a city comfortable for living" has had an average rating of 3.5 and the statement "The attractiveness of tourism offer could be increased by the better valorization of cultural heritage" has got an average rating of 4.3. Then a group of questions has followed related to the identity and image of the city. The answers on the question "What makes the city unique and recognizable" have been very interesting: the majority of local residents has answered it is primarily for its Amphitheatre $(60 \%)$, its rich cultural and historical heritage $(42 \%)$, the sea (7\%) and there has been several associations related to its shipyard, the Film Festival, multiculturalism, the beauty of nature (the Brijuni islands are nearby), the clean sea and beaches. Although it has been a small sample, we can conclude that the local residents also perceive the Arena and the old town as "holders" of the identity and image of the city.
Also, local residents have been asked about the main strengths and weaknesses of the city as a tourist destination. As a major advantage of Pula, they have mentioned the sea, climate and the (richness of cultural and natural) heritage. The first place in the perception of its residence convincing holds the sea, then the history, culture and heritage ("huge fund of monuments in a small space"), position and proximity to emissive markets and resources.

As major weaknesses they have stressed :

1. traffic infrastructure (most complaints);

2. neglectedness of the old city centre; poor management of resources;

3. lack of facilities for entertainment (especially for youth and out of season);

4. unordered Riva, infrastructure problems;

5. industry in the city centre, unused port;

6. high prices;

7. lack of information;

8. extreme seasonality;

9. poor gastro-offer;

10. lack of intersect oral collaboration and networking of politics, culture and tourism.

We have explored as well their perception, awareness, satisfaction, sources of information and frequency of visits related to cultural events in the city. Among its residents, Pula has been perceived as the town of festivals and creative industries ("eventful city", creative city, "the city of movie and book"). Average grade (on the scale 1-5) for the cultural offer of the city has been 3.2. The research has shown that most of local residents relatively regularly (from once a week to once a month), and more often during the summer, visit the theatre, cinema, exhibitions, concerts and festivals. Among the most popular festivals are the Pula Film Festival, the Pula Book Fair, Pula Superiorum, Monte Paradiso, PUF, Seasplash etc. Majority (a half of them) uses the Internet as a source of information about the cultural offer in the town, then the local press (a third), posters, brochures and flyers (a fifth), radio/TV 10\%, and agencies and tourist info-centre only $5 \%$. We have been interested in the degree of awareness of the importance of cultural heritage and the perception of cultural events, and the attitude related to the city's candidacy for European Capital of Culture. We have found that the residents are well-informed about the local attractions. Having been asked to list the five most important sites, they have most frequently mentioned the Amphitheatre, the Temple 
of Augustus and the Roman Forum, the Golden and Twin Gate, the Hercules Gate, the old town and the Castle, the Cultural centre Rojc, the Small Roman Theatre, the fortification system, Uljanik shipyard, Cape Kamenjak and the Brijuni Islands. Regarding the possibility of nomination for the European Capital of Culture, the majority is reserved, a third of them consider the project could positively contribute to improve the image of the city, while $25 \%$ have no information about this project.

As sugestions for improving the cultural and creative tourism offer in the city, they have recommended: to invest in the renovation of the old city, traffic and infrastructure; to invest in culture and education, more events and happenings (especially facilities for the young people), longer openings hours for shops and restaurants, to renew abandoned and forgotten military complexes and to put them into the cultural function; better coordination, networking and education of all culture and tourism structures, to improve cooperation with the civil sector, to organize cultural events all year-round and to improve promotional activities.

\section{Experts}

We have interviewed 15 experts (from the related sectors: tourist industry, culture, local and regional administration, education and science and civil society). Most of them have considered current situation complicated, primarily due to recession and lack of cooperation and coordination between the sectors of culture and tourism. However, they have emphasized the great potential for the development of cultural tourism, primarily because of the rich cultural heritage and developed cultural industries in the town. They have emphasized the need for research and more precise defining of the core values of identity and image the city wants to communicate to the target markets. As the important problems they have cited insufficient strategic thinking of the cultural tourism development, insufficient use of resources of cultural heritage and creative industries in tourism, poor condition of the old town, inadequate promotion and communication, inertia and bureaucratization of the system. They have highlighted the need to encourage entrepreneurship in the field of culture and tourism, which could revive the old town, and stressing the lack of Destination Management Companies, which could design the quality offer off-season.
They consider culture and tourism, and cultural tourism in general as the strategic guidelines for the development of the city. Considering development priorities they have listed the following: defining the main development projects and reaching the public consensus about them, regulating the public infrastructure and put in order the old city centre, defining the most important tourist segments and adjusting the cultural tourism product to them, increasing the level of cultural tourism offer in the city (to attract the greater spending power segment), better presenting the attractions through manifestations and cultural routes, extending the season, taking advantage of good position and increasing the number of airlines and ship- lines, using the European Union funds and networking and the opportunity to develop cross-border projects, improving education and professionalization in the sector of culture and tourism, valorizing the fortification system, involving the civil society and the alternative scene in the cultural and creative tourism offer. Part of them consider the candidature for the European capital of culture title desirable and important for the city, as an opportunity to better valorize and finance the culture, to develop the infrastructure and renew the city centre. Other (cultural workers) are more critical and consider the city at this time does not meet even minimum requirements for candidacy. As a conclusion, they have emphasized the importance of education and professionalization in the field of culture and tourism, and as a positive example they have cited the Interdisciplinary Study Programme of Culture and Tourism, which educates staff that will direct the strategic development of local cultural tourism.

\section{Content analysis - monographs and multimedia}

As the content analysis of multimedia sources and monographs (such as Puna je Pula/Pula is Full of the well known Istrian scientist and writer Mijo Mirković/Mate Balota) shows, the key developmental periods, which formed the identity of Pula were periods of the Roman and Austro-Hungarian rule, and the period after the World War II, when industrial and military city was slowly turning into a regional cultural and tourist centre. Pula, however, currently has a rather undefined image of former military and port city, and is recognized within the broader framework primarily for its shipyard and the 
Roman amphitheatre (Balota, 2005). The city unfortunately minimally uses possibilities offered by a rich multicultural history and preserved heritage, and the fact that it is situated in the specific border contact zone of different cultures and identities.

Ancient identity elements are today especially visible in the abundance of cultural heritage sites and archeological monuments: Arena as an iconic symbol of the city, the extraordinary attractions of the old town (the Triumphal Arch of the Sergy from the 1st century BC, the Hercules Gate and the Twin Gate, the Temple of Augustus and a small Roman Theatre, the Roman Forum), which are still waiting for an adequate evaluation in compliance with the new identity strategies. Archaeology, as a very attractive segment for the contemporary postmodern cultural tourists, is not still widely used, but there are new possibilities, especially in the context of cross-border cultural itineraries. The city generally underutilizes the image of the former Roman colony. Thus, for example, The Ancient Week in May, when interactive costumed performances take place in the city's streets, should be extended to the entire season, and gladiatorial combats could become a permanent and distinctive content and attraction in the roman Amphitheatre. One of the important and unused cultural identity checkpoints certainly is the Kastel (the Castle; one of the seven hills of Pula and the Venetian fortress with the Historical Museum of Istria inside as a repository of collective memory). By testing the opening of one tunnel, this spring has started the valorization of completely ignored potential of "Pula catacombs", 40 kilometers of Austrian shelters in the form of tunnels below the hills of Pula.

Austria has left high-quality architecture to contemporary local residents (beautiful districts, like Veruda villas and parks, but also a powerful fortification system, which still awaits a proper valorization) and the most important urban facilities, such as the former Arsenal, on whose foundations the most famous Croatian shipyard Uljanik arose. The shipyard has become a symbol of the urban identity of the contemporary city. However, the largest Istrian town with a rich maritime tradition has not had its Maritime Museum yet. In the city and regional marketing, the nearby Brioni (Brijuni) Islands, managed by the Austrian visionary industrialist Paul Kupelwieser at the turn of the $19^{\text {th }}$ to the $20^{\text {th }}$ century and meanwhile becoming a world famous elite tourist destination, are not enough promoted.

What more than half a century has defined the cultural image and identity of the city is primarily the Pula Film Festival (since 1953). A part of the city image is given by the nearby Brijuni Islands, where the political and cultural elite have entertained. With growing competition in the field of cultural industries, in the recent decade, there has been a diversification of cultural offerings and creating of new programs, such as the Pula Cultural Summer (the Histria Festival) and attractive music scene in the Arena, the Book Fair in Istria and a series of small cultural projects linking local associations and initiatives in the culture.

Rich cultural and historical heritage, as the attraction base, requires appropriated approaches to the restoration and protection. While the ancient monuments protection has been regulated systematically under the programs of the Ministry of Culture, the architecture of the Austro-Hungarian and later periods is not still covered by the protection programs. The worst situation is certainly in the dramatically neglected old town, which as a dynamic public space with 3000 years of historic continuity has the largest cultural identity potential. Therefore, the right policies of urban revitalization and regeneration of the old city core, which will restore life and vitality to the neglected urban tissue, will be of great importance in the future. Thoughtful concepts and processes of creative reconstruction of the oldest part of the town will be very important, which will include the "treatment" of chronic wounds in the urban tissue by means of culture as a generator of economic prosperity and as the absorber of social tensions, associated with (post) industrial cities in transition and recession, unemployment, pollution and lack of public infrastructure (Švob Đokić, 2007). Derelict and in winter the completely deserted old town and its main "transversal" can and must revive with the help of various forms of cultural tourism and storytelling, based on the redefined identity of the city. In this way, Pula could improve its image as a destination rich of cultural and tourist attractions, which will increase the pleasure of visitors and the quality of life of local residents, stimulate consumption and prolong the season, attract new market segments and investors, and boost year-round cultural and tourist demand.

\section{CONCLUSION AND DISCUSSION}

The conducted research and collected data show that Pula could be considered a typical cultural tourism destination, with an emphasis on heritage tour- 
ism, creative industries, multiculturalism, civil society and the local way of life. Culture is one of the most important motives to visit the city. Although one third of visitors have said the sun and the sea have been the main motive of their visit, a half of the respondents have cited urban, cultural and creative tourism as the main motive for the visit. Local residents, their guests and experts agree that the city is recognizable primarily for its unique cultural, historical and natural heritage, and that the cultural identity "holders" are the Amphitheatre, the old town core with the Roman monuments, turbulent history and multiculturalism, and a unique combination of the atmosphere of the ancient old town by the sea and the former Austria's main naval port with powerful fortification system, which is still waiting for the proper valorization. To develop competitive products on the base of the distinctive cultural identity, it is necessary to point out special features and enhance the unique characteristics of the destination. This means that the planning priorities have to be investing in the "identity holders", such as the old city core, cultural heritage and cultural industries, extending the season through inclusion and integration of attractions in events and cultural routes, valorization of the former military zone and the fortification system and design of new integrated cultural tourism products that could be financed by international funds. One of possibilities, which could significantly contribute to the investments in the cultural infrastructure and facilities, and in the renewing of the old town, is the candidacy for the European Capital of Culture title. Key stakeholders agree that Pula first has to fulfill some essential requirements, such as professionalization and education of experts in the field of culture and tourism, where the newly established Juraj Dobrila University of Pula could play a great role as a scientific research centre of the region with specialized educational programmes such as Interdisciplinary Study Programme of Culture and Tourism.

The research has indicated the great potential for development of cultural and creative tourism through attractions, events and stories covering the most recognizable elements of identity and heritage (the Roman heritage, the Austrian fortresses, the former military complex that could be put in the cultural and tourist function, Mediterranean and Central European identity, the industrial heritage, the military heritage, the alternative scene in the social center "Rojc" etc.). The research has shown that Pula also fits in the concept of an eventful and creative city, as "the city of the movie and the book", with all its festivals (primarily the Pula Film Festival in the summer and The Book Fair in the winter time). Development of cultural and creative tourism could solve typical problems such as seasonality, revitalize the Old Town core, increase employment and attract new and recession-resistant segments of cultural and creative tourists. In consideration of the strategic development of the city, after they have solved infrastructure requirements, the key stakeholders could "play" with stories and identities of the ancient town and, at the same time, the postmodern city, using creative potentials of its citizens and actual and future experts, and some of them have participated in this study.

\section{REFERENCES}

Balota, M. (2005) Puna je Pula. Pula: AmforaPress. (in Croatian)

Institute for Tourism (2003) Development Strategy of Cultural Tourism: From Tourism and Culture to Cultural Tourism. Zagreb: Government of the Republic of Croatia, Ministry of Tourism.

Institute for Tourism (2009) TOMAS Trends, Attitudes and Consumption of Tourists in Croatia 1987-2008 (TOMAS Cultural Tourism) Zagreb: Institute for Tourism.

Ivanovic, M. (2008) Cultural Tourism. Cape Town: JUTA.

Jelinčić, D.A. (2009) Abeceda kulturnog turizma. Zagreb: Meandar Media. (in Croatian)

Jelinčić, D.A. (2010) Kultura, turizam, interkulturalizam. Zagreb: Meandar Media. (in Croatian)

Richards, G. (2007a) ATLAS Cultural Tourism Survey, Summary Report 2007. New York: THHP.

Richards, G. (2007b) Cultural Tourism, Global and Local Perspectives. New York: THHP.

Richards, G. (2009) The Impact of Culture on Tourism. Paris: OECD.

Švob Đokić, N. (2007) The Creative City: Crossing Visions and New Realities in the Region. Zagreb: Institute for International Relations.

UNESCO (1995) Our Creative Diversity, Report of the World Commission on Culture and Development, UNESCO. 


\section{STRENGTHS}

The beauty of nature and the sea

Pleasant climate

The richness and diversity of cultural and natural heritage

Rich attraction base

History and multiculturalism

Advantageous geographical position

Proximity to emissive markets

Tradition

Cultural identity of the city

Belonging to the Mediterranean and the Central European cultural circle

Human capital

Resources

Strong alternative scene

„Eventful" and creative city

New university study programmes

\section{WEAKNESSES}

Traffic and infrastructure problems

Neglectedness of the old city centre; poor management of resources

Undeveloped and unrecognized cultural

tourism product

Lack of facilities for entertainment

Industry in the city centre, unused port

Extreme seasonality

Poor gastro-offer

Lack of programs of urban revitalization, rehabilitation and regeneration

Lack of cultural managers

Inadequate communication strategies

Insufficient intersectoral cooperation

Insufficient awareness of local residents and government about the heritage potential

\section{OPPORTUNITIES}

Global cultural tourism trends

Development of selective forms of tourism

Growth of creative industries

Interregional and cross-border cooperation

Financing from EU funds

Networking of cultural projects and programmes

Creating of DMC and DMO

Development of cultural tourism as a key factor for

sustainable development and intercultural dialogue

Creating new jobs

Investing in scientific research

Nostalgia as a motive for travel

Use of new information and communication technologies

Candidacy for the European Capital of Culture title

\section{THREATS}

Global recession

Changing trends in the global demand

Unresolved environmental and infrastructure problems

Sharp competition of the (potential)

European capitals of culture

Further devastation of the natural and cultural attraction basis

Inadequate communication strategies and poor promotion

Inadequate coordination and networking of programmess and institutions

Undefined image of the city in the global market

SWOT analysis - Pula as a cultural tourism destination

\section{KULTURNI IDENTITET I KULTURNI TURIZAM - IZMEĐU LOKALNOG I GLOBALNOG (PRIMER PULE U HRVATSKOJ)}

\section{Rezime:}

Kulturni identitet i turizam danas su neizbežno povezani: u globalizovanom svetu ujedinjenih vrednosti i dramatičnih ekonomskih, političkih i društvenih promena, turizam postaje prilika za kulturne i društvene kontakte, komunikaciju i kulturnu razmenu. Sve veća potreba za potvrdom lokalnih kulturnih identiteta, kao i potraga turista za identitetom može se posmatrati kao odgovor na globalizaciju kulturnih trendova. U ovom radu, postavili smo hipotezu da kulturni turizam, kao održiva alternativa masovnom turizmu, predstavlja najbolji model za lokalni razvoj u turbulentnom globalnom kontekstu, jer optimalno koristi autentične karakteristike destinacija i jedinstvene elemente identiteta da bi ih razlikovao od konkurencije. Na taj način, štiti i jača kulturni identitet, vrednosti, životni stil i privredu lokalnih zajednica. Da bismo testirali našu hipotezu, sproveli smo osnovno istraživanje. Koristili smo hibridnu metodološku strategiju, kombinujući kvantitativne i kvalitativne metode kako bi se ispitalo 417 turista, 296 predstavnika lokalnog stanovništva i 15 stručnjaka. Sproveli smo paralelnu analizu sadržaja monografija i multimedijskih izvora. Prikupljeni podaci pokazali su da su ključni elementi identiteta destinacije: turizam baštine, kreativne industrije, multikulturalnost i lokalni način života.
Ključne reči:

kulturni identitet, kulturni turizam, menadžment destinacije, Pula. 